\title{
Олена М. Ніфатова
}

Киӥвський національний університет технологій та дизайну, Украӥна

\section{ІНСТИТУЦЙНЕ ЗАБЕЗПЕЧЕННЯ КОМПЛЕКСНОЇ СИСТЕМНОЇ ПІДТРИМКИ СОЦІАЛЬНОЇ АДАПТАЦІЇ ТА РЕІНТЕГРАЦІЇ УЧАСНИКІВ ООС (АТО) І ВПО}

У статті висвітлено питання щзодо інституційного забезпечення комплексної системної підтримки соціальної адаптащії та реінтегращії учасників операчії об'єднаних сил (кол. АТО) та внутрішньо переміщених осіб (ВПО). Проведено аналіз «Програми підтримки, сочіальної адаптації та реінтеграції громадян України, які переселилися 3 тимчасово окупованої території Украӥни та районів проведення антитерористичної операції в інші регіони України», а також законів та рімень Уряду, щуо регулюють процес забезпечення підтримки соиіальної адаптації зазначеного контингенту в частині ефективного використання їх трудового потенціалу. Дослідження напрямів сприяння інтеграції та сочіальній адаптації ВПО та учасників ООС (АТО) надало підстави розглядати інтеграцію переселенців у місиеве співтовариство як послідовність таких етапів: попередній етап, де діють чинники інтеграчій; початковий (адаптаиійний); модифікаційний (перетворювальний), де відбувається реалізація умов інтеграції; результуючий, щзо відтворює показники інтегращії. Встановлено, щзо високий ступінь інтеграчії передбачає: вирівнювання більшості сочіальних та економічних показників; ідентифікацію переселенців як рівноправних суб'єктів місцевої громади; безконфліктну взаємодію; ефективну співпрачю, партнерство; стійку взаємодію на різних рівнях; задоволеність соціальним статусом, комфортність; позитивне сприйняття оточення $i$ себе в ньому; позитивну динаміку демографічних показників; зв'язок майбутнього спільноти з нарощуванням трудового потенщіалу країни. За результатами проведеного дослідження особливостей інституиійного забезпечення комплексної системної підтримки соиіальної адаптації та реінтеграції учасників ООС (АТО) і ВПО сформовано та систематизовано напрями сприяння інтегращії та соціальній адаптащії відповідного контингенту.

Ключові слова: сочіальна адаптація; реінтеграція; внутрішньо переміщені особи (ВПО); учасники бойових дій.

\section{Елена М. Нифатова}

\section{Киевский национальный университет технологий и дизайна, Украина \\ ИНСТИТУЦИОНАЛЬНОЕ ОБЕСПЕЧЕНИЕ КОМПЛЕКСНОЙ СИСТЕМНОЙ ПОДДЕРЖКИ СОЦИАЛЬНОЙ АДАПТАЦИИ И РЕИНТЕГРАЦИИ УЧАСТНИКОВ ООС (АТО) И ВПЛ}

В статье освещень вопросы институционального обеспечения комплексной системной поддержки социальной адаптащчи и реинтеграции участников операции объединенных сил (ранее АТО) и внутренне перемещенных лии (ВПЛ). Проведен анализ «Программы поддержки, сочиальной адаптащии и реинтеграџии граждан Украины, которые переселились из временно оккупированной территории Украины и районов проведения антитеррористической операчии в другие регионы Украиныл», а также законов и решений Правительства, регулирующих прочесс обеспечения поддержки социальной адаптации контингента в части эффективного использования трудового потенциила. Исследование направлений содействия интеграџии и сочиальной адаптации ВПО и участников ООС (АТО) позволило рассматривать интеграцию переселенцев в местное сообщество как последовательность следующих этапов: предварительный этап, где действуют факторы интеграции; начальный (адаптационный); модификационный (преобразовательный), где происходит реализащия условий интегращии; результирующий, 
что воспроизводит показатели интеграции. Установлено, что высокая степень интеграции предполагает: выравнивание большинства социальных и экономических показателей; идентификацию переселенцев как равноправных субъектов местного сообщества; бесконфликтное взаимодействие; эффективное сотрудничество, партнерство; стойкое взаимодействие на различных уровнях; удовлетворенность сочиальным статусом, комфортность; позитивное восприятие окружения и себя в нем; положительную динамику демографических показателей; связь будущего сообщества с наращиванием трудового потенциала страны. По результатам исследования особенностей институционального обеспечения комплексной системной поддержки сочиальной адаптации и реинтеграции участников ООС (АТО) и ВПО сформированы и систематизировань направления содействия интеграции и соџиальной адаптации соответствующего контингента.

Ключевые слова: социиальная адаптащия; реинтеграция; внутренне перемещенные лиияа (ВПЛ); участники боевых действий.

\section{Olena M. Nifatova \\ Kyiv National University of Technologies and Design, Ukraine \\ INSTITUTIONAL INTEGRATED SYSTEMIC SUPPORT FOR SOCIAL ADAPTATION AND REINTHEGRATION OF UFO (ATO) PARTICIPANTS AND IDPs}

The paper discusses the issues of institutional integrated systematic support for ensuring social adaptation and reintegration of United Forces Operation (UFO) (formerly ATO) participants and internally displaced persons (IDPs). Insights are provided on the "Program of support, social adaptation and reintegration of Ukrainian citizens who moved from the temporarily occupied territory of Ukraine and areas of the anti-terrorist operation to other regions of Ukraine" along with the laws and Government regulations on the maintenance of social adaptation of the above population group in terms of efficient utilization of their labor potential. The study of different dimensions in promoting integration and social adaptation of the IDPs and UFO (ATO) participants allowed to identify the following subsequent stages in the process of integration of displaced persons into the local community: the preliminary phase affected by the integration factors; initial (adaption period); modification (transformation) stage related to the integration implementation; and the resultant one reinforcing the integration indicators. It has been revealed that large-scale integration involves: adjustment of a range of social and economic indicators; ensuring equal treatment to migrants within local community; providing conflict-free interaction; effective cooperation and partnership; long-lasting multi-level relationships; satisfaction with social status, comfort; positive perception of the environment in harmony with self-perception; positive demographic dynamics; linking the future of the community with the national labor potential enhancement. The research findings on the specifics of providing the institutional integrated systematic support for social adaptation and reintegration of UFO (ATO) participants and IDPs have enabled to build up and generalize the dimensions for promoting integration and social adaptation of the given population group concerned.

Keywords: social adaptation; reintegration; internally displaced persons (IDPs); combat participants.

Постановка проблеми. Реалії сьогодення нашої держави вимагають від України зміщення стратегічних орієнтирів в зону розвитку та підтримки сприятливого соціальноекономічного середовища для реалізації трудового потенціалу незахищених верств населення, зокрема демобілізованих учасників із зони бойових дій. Трудовий потенціал цієї категорії населення може бути ефективно реалізований тільки за умови належної державної підтримки та соціально-економічного сприяння. Більше того, сприяння розвитку малого та середнього підприємництва серед зазначеної категорії населення може стати потужним 
інструментом не тільки соціальної адаптації до мирного життя та реінтеграції учасників ОСС (АТО), ВПО, але й продукувати економічний та соціальний ефекти як на рівні нашої держави, так і за іiі межами. Так, наприклад, у 2015 році державою було запроваджено «комплексну програму підтримки, соціальної адаптації та реінтеграції громадян України, які переселилися 3 тимчасово окупованої території України та районів проведення антитерористичної операції в інші регіони України». Прийняті на сьогоднішній день Верховною Радою закони та рішення Уряду нашої держави суттєво впливають на забезпечення комплексної, системної підтримки соціальної адаптації та реінтеграції ВПО та учасників ООС (АТО) в частині ефективного використання їх трудового потенціалу вплинули, що виражається через застосування нормативно-правових актів, які визначають особливості їх розміщення та працевлаштування. Проте, слід зазначити, що ряд важливих проблем, які безпосередньо стосуються забезпечення комплексності та системності у підтримці соціальної адаптації та реінтеграції зазначених верст населення, залишилися не відкритими та актуальними для вивчення.

Аналіз останніх джерел, досліджень та публікацій. Основу теоретикометодологічної бази дослідження формують напрацювання вітчизняних та зарубіжних вчених щодо проблеми соціально-економічної адаптації та реабілітації не захищених верств населення, зокрема ветеранів бойових дій, а також роботи, присвячені інституційному забезпеченню комплексної, системної підтримки соціальної адаптації та реінтеграції учасників ООС (АТО), ВПО.

Багато робіт науковців, присвячено проблемі розвитку та адаптації трудового потенціалу внутрішньо переміщених осіб в Україні. Так, наприклад, К. Ніколаєць акцентує свою увагу на дослідженні впливу ВПО на формування трудових ресурсів регіонів України [1]. О.В. Кладова та П.В. Ворона розглядають та доводять важливість підтримки державою різноманітних форм надання психологічної та соціальної допомоги учасникам бойових дій та внутрішньо переміщеним особам $[2,3]$. Не залишається поза увагою науковців і питання, пов'язане 3 вивченням проблеми залучення до підприємництва учасників ООС (АТO). О.А. Сороківська пропонує у якості дієвого інструменту формування сприятливої політики ведення малого і середнього бізнесу запровадження системи дорожніх карт за регіонами країни [4].

Метою статті є дослідження особливостей інституційного забезпечення комплексної, системної підтримки соціальної адаптації та реінтеграції учасників ООС (АТО), ВПО.

Результати дослідження. 16 грудня 2015 року Кабінетом Міністрів України було затверджено Комплексну державну програму щодо підтримки, соціальної адаптації та реінтеграції громадян України, які переселилися з тимчасово окупованої території України та районів проведення антитерористичної операції в інші регіони України, на період до 2017 року. Головною метою Програми стало «розв'язання проблем громадян України, які переселилися 3 тимчасово окупованої території України та районів проведення антитерористичної операції в інші регіони України, та зниження рівня соціальної напруженості серед них і в суспільстві; сприяння інтеграції та соціальній адаптації таких осіб за новим місцем проживання; допомога в забезпеченні створення належних умов для життєдіяльності, прав та реалізації потенціалу; забезпечення соціальної, медичної, психологічної та матеріальної підтримки; створення передумов для компенсації завданої їм майнової (матеріальної) та моральної шкоди; створення сприятливих умов для добровільного повернення на місця попереднього проживання (за умови повного фактичного припинення бойових дій на територіях, на яких органи державної влади тимчасово не здійснюють свої повноваження)» [5]. 
Зазначена державна програма передбачає подолання низки проблемних питань, виявлених за результатами аналізу ситуації з внутрішньо переміщеними особами та учасниками ООС (АТО), основний сутнісний зміст яких представлено на рис. 1.

\begin{tabular}{|c|c|}
\hline $\begin{array}{c}\text { Правове } \\
\text { забезпечення }\end{array}$ & $\begin{array}{l}\text { Надання правової допомоги, підвищення рівня правової грамотності } \\
\text { серед переселених громадян, удосконалення законів і розроблення } \\
\text { чітких інструкцій щодо їх реалізації, напрацювання механізму } \\
\text { захисту прав і компенсації переселеним громадянам завданої їм } \\
\text { майнової (матеріальної) та моральної шкоди. }\end{array}$ \\
\hline $\begin{array}{l}\text { Соціально- } \\
\text { економічне } \\
\text { забезпечення }\end{array}$ & $\begin{array}{l}\text { Збереження гарантій державного соціального забезпечення та } \\
\text { захисту переселених громадян, надання їм матеріальної підтримки з } \\
\text { метою забезпечення нормального рівня життя та недопущення } \\
\text { злиденності, сприяння створенню робочих місць, } \\
\text { працевлаштуванню та самозайнятості, забезпечення доступності до } \\
\text { освітніх послуг, сприяння будівництву постійного, тимчасового та } \\
\text { соціального житла, підтримки статутної діяльності громадських } \\
\text { об'єднань переселених громадян. }\end{array}$ \\
\hline $\begin{array}{c}\text { Медичне } \\
\text { забезпечення }\end{array}$ & $\begin{array}{l}\text { Збереження гарантій державного медичного обслуговування, } \\
\text { надання комплексного медичного забезпечення в місцях } \\
\text { компактного проживання, надання психосоціологічної допомоги } \\
\text { особам, постраждалим внаслідок воєнних дій, створення умов для } \\
\text { збереження здоров'я переселених громадян у нових умовах } \\
\text { життєдіяльності. }\end{array}$ \\
\hline $\begin{array}{c}\text { Транспортне } \\
\text { забезпечення }\end{array}$ & $\begin{array}{l}\text { Надання необхідних транспортних послуг для евакуації цивільного } \\
\text { населення із зони бойових дій та для інших потреб переселених } \\
\text { громадян }\end{array}$ \\
\hline $\begin{array}{c}\text { Побутове } \\
\text { забезпечення }\end{array}$ & $\begin{array}{l}\text { Створення необхідних комунальних та побутових умов для } \\
\text { життєдіяльності переселених громадян, забезпечення доступності } \\
\text { до закладів побутової та соціальної інфраструктури }\end{array}$ \\
\hline $\begin{array}{l}\text { Культурне та } \\
\text { патріотично- } \\
\text { виховне } \\
\text { забезпечення }\end{array}$ & $\begin{array}{l}\text { Сприяння збереженню традиційної культури, забезпечення іiї } \\
\text { неконфліктної інтеграції з національною культурою та культурними } \\
\text { традиціями населення територій, з яких здійснюється переміщення, } \\
\text { виховання та розвиток патріотичних почуттів, сприяння духовному } \\
\text { розвитку переселених громадян }\end{array}$ \\
\hline $\begin{array}{l}\text { Організаційно- } \\
\text { інформаційне } \\
\text { забезпечення }\end{array}$ & $\begin{array}{l}\text { Створення системи збору інформації про стан та потреби } \\
\text { переселених громадян, забезпечення иї систематизації, аналізу та } \\
\text { оприлюднення, залучення інститутів громадянського суспільства до } \\
\text { проведення постійного незалежного моніторингу, узагальнення, } \\
\text { аналізу та контролю здійснення заходів і результатів виконання } \\
\text { Програми. }\end{array}$ \\
\hline
\end{tabular}

Рис. 1. Напрями сприяння інтеграції та соціальній адаптації ВПО та учасників ООС (АTO) 
Вимушено переміщені особи зі сходу України та Автономної республіки Крим на сьогоднішній день мають потребу не тільки в матеріальному забезпеченні, засобах першої необхідності та забезпеченні побутових умов. На перше місце постають проблеми соціальної адаптації на новому місці, у незвичних умовах. Для подолання зазначених суперечностей здійснюється впровадження окремих районних програм, головною ціллю яких є адаптація вимушено переміщених осіб, в частині надання їм консультативної допомоги, допомого у правильності оформлення відповідних документів, знайомство 3 регіоном (його особливостями та звичаями), до якого вони були переміщені, а найголовніше - надання докладної інформації стосовно потреб у трудовому потенціалі регіону, а також затребуваних вакансій на ринку праці. Крім того, для бажаючих отримати підтримку для ведення індивідуальної підприємницької діяльності, надається можливість відвідати безкоштовні курси з основ підприємницької діяльності. В рамках таких районних програм, відбувається постійна співпраця зі службами зайнятості та роботодавцями регіонів, 3 метою формування списку вакансій, які пропонуються тим, що звернулися до управління. Інституціональне забезпечення для розроблення таких програм базується на законі України «Про забезпечення прав і свобод внутрішньо переміщених осіб» [6], «Про внесення змін до деяких законів України щодо посилення гарантій дотримання прав і свобод внутрішньо переміщених осіб» [7], постанови КМУ «Про облік осіб, які переміщуються з тимчасово окупованої території України та районів проведення антитерористичної операції» [8], «Про надання щомісячної адресної допомоги особам, які переміщуються з тимчасово окупованої території України та районів проведення антитерористичної операції, для покриття витрат на проживання, в тому числі на оплату житлово-комунальних послуг» [9].

Акцентуючи увагу на взаємозалежності між вимушеною міграцією та інтеграцією, а також, на факторах і умовах їі динаміки, на оцінках стійкості мігрантів в соціумі, доцільно етапність інтеграції переселенців в місцеве співтовариство розглядати як одну 3 їі особливостей. У цьому контексті слід виділити наступні етапи:

1) попередній етап, де діють чинники інтеграції;

2) початковий (адаптаційний);

3) модифікаційний (перетворювальний), де відбувається реалізація умов інтеграції;

4) результуючий, що відтворює показники інтеграції.

Попередній етап характеризується дією таких чинників інтеграції, як негативна зміна зовнішнього оточення, військово-політичні (військові дії, зміна державних кордонів), соціально-психологічні (почуття безпеки). Загроза життю, неможливість перебування на колишній території за політичними та морально-психологічних причинами обумовлюють об'єктивність, антигуманність і стихійність початку безповоротної міграції та інтеграції. Оформлення мотивів інтеграції як усвідомленого спонукання до діяльності, спрямованої на «приєднання» до нової спільноти (інтеграційна мобільність) зв'язується з виникненням i усвідомленням потреби в раціональному і ціннісно-прийнятному для інтеграції соціумі, де $\epsilon$ умови фізичної і соціальної безпеки, захисту від депривації, що характерно для попереднього етапу інтеграції і означає підготовку до початку нового життя, сенс і зміст якої зв'язується 3 адаптацією в іншому співтоваристві і інтеграція в нього.

Початковий (адаптаційний) етап. Знання про даний етап інтеграції базуються на розумінні нової соціальної реальності і середовища проживання, властивістю якої по відношенню до переселенця $\epsilon$ ризик. Майнові втрати і втрата матеріальних ресурсів, моральні і психологічні втрати, новизна, непередбачуваність подій ставлять переселенців в ситуацію, яка пов'язана із сукупністю проблем, обумовлених їх переходом від стану визначеності до невизначеності. 
Модифікаційний (перетворювальний) етап інтеграції. Знання про даний етап базується на сукупності концепцій i концептуальних положень, спрямованих на обгрунтуванні суб'єктивної поведінки індивідів в життєвому просторі: 3 концепцією життєвого світу в сфері «горизонтальних» зв'язків людини; 3 принципом сітуаціоналізма [10], де основним є положення про те, що соціальний контекст пробуджує до життя потужні сили, що стимулюють або обмежують поведінку; 3 концепцією радикальної соціальності [11], згідно 3 якою «проблема суб'єктивності поступово перетворюється в проблему суб'єктивності індивідів як сили і форми розвитку соціальності» 3 концепцією життєвих сил людини [12], яка призводить до перспективи вимірів соціальної реальності, зокрема, здатності людей виживати, охороняти своє життя в мінливих умовах.

Модифікаційний етап полягає у проведенні інформативних та навчальних заходів щодо мотивації відкриття власної справи та розвитку підприємницької ініціативи шляхом залучення бізнес-консультантів та викладачів ВНЗ для супроводу проектів учасників ООС (АТО). Слід зазначити, що саме на цьому етапі важливим є синергетичне поєднання соціальних інновацій у сфері підприємництва та освіти. Залучення соціальних інвестицій та використання соціально-інноваційних технологій надасть можливість створити комплексну адаптаційну систему, функціонування якої спрямоване на ефективну адаптацію майбутніх підприємців.

Результуючий етап. Даний етап характеризує ступінь соціокультурної інтеграції, або інтегрованості, мігрантів до місцевої спільноти.

Високий ступінь інтеграції - це: вирівнювання більшості соціальних та економічних показників; ідентифікація переселенців як рівноправних суб'єктів місцевої громади; безконфліктна взаємодія; ефективна співпраця, партнерство; стійка взаємодія на різних рівнях; задоволеність соціальним статусом, комфортність; позитивне сприйняття оточення i себе в ньому; позитивна динаміка демографічних показників; зв'язок майбутнього 3 спільнотою і нарощування ресурсів.

Висновки та пропозиції. Таким чином, дослідження особливостей інституційного забезпечення комплексної, системної підтримки соціальної адаптації та реінтеграції учасників ООС (АТО), ВПО надало можливість сформувати та систематизувати напрями сприяння інтеграції та соціальній адаптації відповідного контингенту. Акцентуючи увагу на взаємозалежності між вимушеною міграцією та інтеграцією, а також, на факторах і умовах їі динаміки, на оцінках стійкості мігрантів в соціумі було виокремлено та детально описано етапи інтеграції. Такий підхід дозволить підвищити рівень інтеграції учасників ООС (АТО) та вимушено переміщених осіб у соціумі та створить підгрунтя для продукування економічного та соціального ефектів за рахунок підвищення ефективності використання трудового потенціалу, як на рівні нашої держави, так і за ії межами.

Робота виконана за підтримки Міністерства освіти $і$ науки України в рамках проекту 16.04 .55 ДБ «Інновачійна платформа бізнес-освіти на основі кластерного підприємнищтва для демобілізованих воїнів та переселенџів із зони АТО».

\section{References}

\section{Література}

1. Nikolaiets, K. (2017). Trudovyi potentsial vnutrishno 1 1. Ніколаєць К. Трудовий потенціал peremishchenykh osib v Ukraini [The labor potential of внутрішньо переміщених осіб в Україні / internal migrants in Ukraine]. Visnyk KNTEU [Herald К. Ніколаєць // Вісник КНТЕУ. - 2017. of KNUTE], No. 4, P. 42-53 [in Ukrainian].

2. Kladova, O.V. (2015). Sotsialna robota shchodo 2. Кладова О. В. Соціальна робота щодо zhyttiezabezpechennia vnutrishno peremishchenykh життєзабезпечення внутрішньо переміosib u Luhanskii oblasti [Social work on the life щених осіб у Луганській області / support of internally displaced people in the Lugansk О. В. Кладова // Ринок праці та 
region]. Rynok pratsi ta zainiatist naselennia [Labor|зайнятість населення. - 2015. - № 3. market and employment of the population.], No. 3, C. 51-53 [in Ukrainian].

P. 51-53 [in Ukrainian].

3. Vorona, P.V. (2018). Shliakhy sotsialnoi 3. Ворона П. В. Шляхи соціальної reabilitatsii uchasnykiv ukrainsko-rosiiskoi viiny na peабілітації учасників українськоskhodi Ukrainy: zarubizhnyi dosvid [Ways of social pociйської війни на сході України: rehabilitation of participants of Ukrainian-Russian war зарубіжний досвід [Електронний ресурс] in the east of Ukraine: international experience]. / П. В. Ворона // Вісник Національного Bulletin of National University of Civil Protection of університету цивільного захисту Ukraine. State Management series, Vol. 1(8). України. Серія: Державне управління. Retrieved from: DOI: 10.5281/zenodo.1240793 [in 2018. - Вип. 1 (8). - Режим доступу: Ukrainian].

DOI: 10.5281 /zenodo.1240793.

4. Sorokivska, O.A., Mosii, O.B., Kuzhda, T.I. (2017). 4. Сороківська О. А. Відкриття власної Vidkryttia vlasnoi spravy yak shliakh sotsialno- справи як шлях соціально-економічної ekonomichnoi adaptatsii veteraniv ATO [Opening of адаптації ветеранів АТО / own business as a way of social and economic O. А. Сороківська, adaptation of ATO veterans]. Innovatsiina ekonomika T. I. Кужда // Інноваційна економіка. [Innovative economy], No. 5, P. 139-115 [in Ukrainian]. 2017. - № 5. - C. 139-115.

5. Pro zatverdzhennia Kompleksnoi derzhavnoi 5. Про затвердження Комплексної prohramy shchodo pidtrymky, sotsialnoi adaptatsii ta державної програми щодо підтримки, reintehratsii hromadian Ukrainy, yaki pereselylysia z соціальної адаптації та реінтеграції tymchasovo okupovanoi terytorii Ukrainy ta raioniv громадян України, які переселилися 3 provedennia antyterorystychnoi operatsii $\mathrm{v}$ inshi тимчасово окупованої території України rehiony Ukrainy, na period do 2017 roku [On та районів проведення антитерорисApproval of the Integrated State Program for Support, тичної операції в інші регіони України, Social Adaptation and Reintegration of Ukrainian на період до 2017 року: Постанова Citizens Moved from the Temporarily Occupied Кабінету Міністрів України № 1094 від Territory of Ukraine and Areas of Anti-Terrorist 16.12.2015 [Електронний ресурс]. Operation to Other Regions of Ukraine for the Period Режим доступу: https://zakon.rada.gov.ua/ until 2017: Resolution of the Cabinet of Ministers of laws/show/1090-2017-\%D0\%BF\#n2.

Ukraine No. 1094 dated 16.12.2015]. Retrieved from: https://zakon.rada.gov.ua/laws/show/1090-2017-

$\% \mathrm{D} 0 \% \mathrm{BF} \# \mathrm{n} 2$ [in Ukrainian].

6. Pro zabezpechennia prav i svobod vnutrishno 6. Про забезпечення прав і свобод peremishchenykh osib [On ensuring the rights and внутрішньо переміщених осіб: Закон freedoms of internally displaced persons: Law of України із змінами від 20.10.2014 Ukraine with amendments dated 20.10.2014 No. 1706- № 1706-VII [Електронний ресурс]. VII]. Retrieved from: https://zakon.rada.gov.ua/laws/ Режим доступу: https://zakon.rada.gov.ua/ show/1706-18 [in Ukrainian].

7. Pro vnesennia zmin do deiakykh zakoniv Ukrainy 7. Про внесення змін до деяких законів shchodo posylennia harantii dotrymannia prav i України щодо посилення гарантій svobod vnutrishno peremishchenykh osib [Оn дотримання прав i свобод внутрішньо Amendments to Some Laws of Ukraine on переміщених осіб: Закон України від Strengthening the Guarantees of the Observance of the 24.12.2015 № 921-VIII [Електронний Rights and Freedoms of Internally Displaced Persons: pecypc]. - Режим доступу: https://zakon. Law of Ukraine dated December 24, 2015, No. 921- rada.gov.ua/laws/show/921-19.

VIII]. Retrieved from: https://zakon.rada.gov.ua/laws/ show/921-19 [in Ukrainian]. 
8. Pro oblik vnutrishno peremishchenykh osib [About|8. Про облік внутрішньо переміщених registration of internally displaced persons: Resolution осіб: Постанова Кабінету Міністрів of the Cabinet of Ministers of Ukraine dated України від 1.10.2015 № 509 01.10.2015 No. 509]. Retrieved from: https://[Електронний ресурс]. - Режим доступу: zakon.rada.gov.ua/laws/show/509-2014-\%D0\%BF [in https://zakon.rada.gov.ua/laws/show/509Ukrainian].

9. Pro nadannia shchomisiachnoi adresnoi dopomohy 2014-\%D0\%BF.

osobam, yaki peremishchuiutsia $\mathrm{z}$ tymchasovo okupovanoi terytorii Ukrainy ta raioniv provedennia antyterorystychnoi operatsii, dlia pokryttia vytrat na prozhyvannia, $\mathrm{v}$ tomu chysli na oplatu zhytlovokomunalnykh posluh [On the provision of monthly targeted assistance to persons who move from the temporarily occupied territory of Ukraine and areas of the anti-terrorist operation to cover the cost of living, including for payment of housing and communal services: Resolution of the Cabinet of Ministers of Ukraine dated 10.10.2014 No. 505]. Retrieved from: https://zakon.rada.gov.ua/laws/show/505-2014$\% \mathrm{D} 0 \% \mathrm{BF}$ [in Ukrainian].

10. Levin, K. (2001). Dinamicheskaia psikhologiia [Dynamic psychologist]. Moscow: Smysl. 572 p. [in Russian].

11. Kemerov, V.E. (1999). Kontceptciia radikalnoi sotcialnosti [The concept of radical sociality]. Voprosy filosofii [Philosophy Issues], No. 7, P. 3-13 [in Russian].

12. Ross, L., Nisbett, R. (1999). Chelovek i situatciia. Perspektivy sotcialnoi psikhologii [Man and situation. Perspectives of social psychology]. Translation from English V.V. Rumynskii; Ed. E.N. Emelyanov, B.C. Magun. Moscow: Aspekt Press. 429 p. [in Russian].

9. Про надання щомісячної адресної допомоги особам, які переміщуються 3 тимчасово окупованої території України та районів проведення антитерористичної операції, для покриття витрат на проживання, в тому числі на оплату житлово-комунальних послуг: Постанова Кабінету Міністрів України від 1.10.2014 № 505 [Електронний pecypc]. - - Режим доступу: https://zakon.rada.gov.ua/laws/show/5052014-\%D0\%BF.

10. Левин К. Динамическая психология / К. Левин. - М.: Смысл, 2001. - 572 с.

11. Кемеров В. Е. Концепция радикальной социальности / В. Е. Кемеров // Вопросы философии. - 1999. - № 7. C. 3-13.

12. Росс Л. Человек и ситуация. Перспективы социальной психологии / Л. Росс, Р. Нисбетт; пер. с англ. В. В. Румынского; под ред. Е. Н. Емельянова, В. С. Магуна. - М.: Аспект Пресс, 1999. - 429 с. 